\title{
DOE FINAL REPORT
}

Project Title: Studies on the Microbial Formation of Methane

Principal Investigator: Ralph S. Wolfe

Period of Time Final Report Covers: 01/01/87 through 12/31/00

Name and Address of Recipient Organization:

The Board of Trustees of the

University of Illinois

c/o Grants and Contracts Office

109 Coble Hall

801 South Wright Street

Champaign, IL 61820-6242

DOE Grant Number: DE-FG02-87ER13651

Submitted to: U.S. Department of Energy

Chicago Operations Office

Acquisition and Assistance Group

9800 South Cass Avenue

Argonne, IL 60439

Final Report Date: April 2001

NOTICE

This report was prepared as an account of work sponsored by the United States Government. Neither the United States nor the United States Department of Energy, nor any of their employees, nor any of their contractors, subcontractors, or their employees, makes any warranty, express or implied, or assumes any legal liability or responsibility for the accuracy, completeness, or usefulness of any information, apparatus, product or process disclosed or represents that its use would not infringe privately-owned rights.

Ralph S. Wolfe
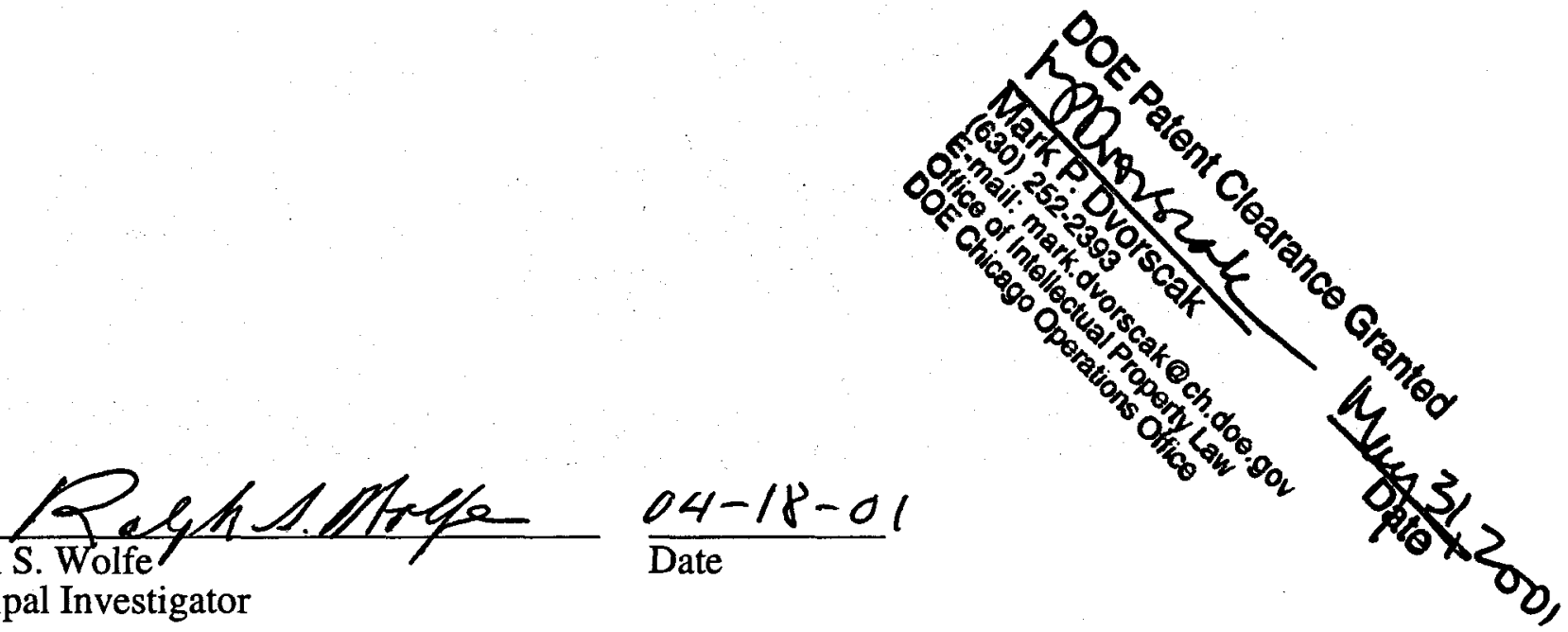

Principal Investigator 


\section{DISCLAIMER}

This report was prepared as an account of work sponsored by an agency of the United States Government. Neither the United States Government nor any agency thereof, nor any of their employees, makes any wartanty, express or implied, or assumes any legal liability or responsibility for the accuracy, completeness, or usefulness of any information, apparatus, product, or process disclosed, or represents that its use would not infringe privately owned rights. Reference herein to any specific commercial product, process, or service by trade name, trademark, manufacturer, or otherwise does not necessarily constitute or imply its endorsement, recommendation, or favoring by the United States Government or any agency thereof. The views and opinions of authors expressed herein do not necessarily state or refiect those of the United States Government or any agency thereof. 


\section{DISCLAIMER}

Portions of this document may be illegible in electronic image products. Images are produced from the best available original document. 
I. FINAL REPORT 01/01/87 through 12/31/00

Grant DE-FG02-87ER13651

Studies on the Microbial Formation of Methane
A. Objectives
No change
B. Experimental Results

\section{$\underline{1987}$}

Bobik, T. A., M. I. Donnelly, K. L. Rinehart, Jr., and R. S. Wolfe. 1987. Structure of a methanofuran derivative found in cell extracts of Methanosarcina barkeri. Arch. Biochem. Biophys. 254:430-436.

Rouvière, P. E., and R. S. Wolfe. 1987. Use of subunits of the methylreductase protein for taxonomy of methanogenic bacteria. Arch. Microbiol. 148:253-259.

Bobik, T. A., K. D. Olson, K. M. Noll, and R. S. Wolfe. 1987. Evidence that the heterodisulfide of coenzyme $M$ and 7-mercaptoheptanoylthreonine phosphate is a product of the methylreductase reaction in Methanobacterium. Biochem. Biophys. Res. Commun. 149:455-460.

\section{$\underline{1988}$}

Bobik, T. A., and R. S. Wolfe. 1988. Physiological importance of the heterodisulfide of coenzyme $M$ and 7-mercaptoheptanoylthreonine phosphate in the reduction of carbon dioxide to methane of Methanobacterium. Proc. Natl. Acad. Sci. USA 855:60-63.

Rouvière, P. E., T. A. Bobik, and R. S. Wolfe. 1988. Reductive activation of the methylcoenzyme M methylreductase system of Methanobacterium thermoautotrophicum $\Delta H$. J. Bacteriol. 170:3946-3952.

Widdel, F., P. E. Rouvière, and R. S. Wolfe. 1988. Classification of secondary alcohol-utilizing methanogens including a new thermophilic isolate. Arch. Microbiol. 150:477-481.

\section{9}

Bobik, T. A., and R. S. Wolfe. 1989. Activation of formylmethanofuran synthesis in cell extracts of Methanobacterium thermoautotrophicum. J. Bacteriol. 171:14231427.

Rouvière, P.E., and R. S. Wolfe. 1989. Component A3 of the methylcoenzyme M methylreductase system of Methanobacterium thermoautotrophicum $\Delta H$ : Resolution into two components. J. Bacteriol. 171:4556-4562.

Widdel, F., and R. S. Wolfe. 1989. Expression of secondary alcohol specific enzyme from Methanogenium thermophilum strain TCI. Arch. Microbiol. 152:322-328. 
1990

DiMarco, A. A., K. A. Sment, J. Konisky, and R. S. Wolfe. 1990. The formylmethanofuran:tetrahydromethanopterin formyltransferase from Methanobacterium thermoautotrophicum $\Delta \mathrm{H}$. Nucleotide sequence and functional expression of the cloned gene. J. Biol. Chem. 265:472-476.

DiMarco, A. A., T. A. Bobik, and R. S. Wolfe. 1990. Unusual coenzymes of methanogenesis. Annu. Rev. Biochem. 59:355-394.

Wolfe, R. S. 1990. Novel coenzymes of archaebacteria, 41. Colloquium Mosback. Molecular Basis of Bacterial Metabolism. Springer-Verlag, Berlin Heidelberg.

Bobik, T. A., A. A. DiMarco, and R. S. Wolfe. 1990. Formyl-methanofuran synthesis in Methanobacterium thermoautotrophicum. FEMS Microbiol. Rev. 87:323-326.

1991

Olson, K. D., C. W. McMahon, and R. S. Wolfe. 1991. Light sensitivity of methanogenic archaebacteria. Appl. Environ. Microbiol. 57:2683-2686.

Olson, K. D., C. McMahon, and R. S. Wolfe. 1991. Photoactivation of the 2(methylthio)ethanesulfonic acid reductase from Methanobacterium. Proc. Natl. Acad. Sci. USA 88:4099-4103.

1992

Olson, K. D., L. Chmurkowska-Cichowlas, C. W. McMahon, and R. S. Wolfe. 1992. Structural modifications and kinetic studies of the substrates involved in the final step of methane formation in Methanobacterium thermoautotrophicum. J. Bacteriol. 174:10071012.

Olson, K. D. 1992. Modified bottle plate for the cultivation of strict anaerobes. J. Microbiol. Methods 14:267-269.

1993

Kuhner, C. H., B. D. Lindenbach, and R. S. Wolfe. 1993. Component A2 of the methylcoenzyme M reductase system from Methanobacterium thermoautotrophicum $\Delta \mathrm{H}$ : Nucleotide sequence and functional expression by E. coli. J. Bacteriol. 175:3195-3203.

Woo, G. J., A. Wasserfallen, and R. S. Wolfe. 1993. Methyl viologen hydrogenase II, a new member of the hydrogenase family from Methanobacterium thermoautotrophicum $\Delta$ H. J. Bacteriol. 175:5970-5977.

1996

Metcalf, W. W., J.-K. Zhang, X. Shi, and R. S. Wolfe. 1996. Molecular, genetic, and biochemical characterization of the serC gene of Methanosarcina barkeri Fusaro. J. Bacteriol. 178:5797-5802. 
Metcalf, W. W., J.-K. Zhang, E. Apolinario, K. R. Sowers, and R. S. Wolfe. 1997. A genetic system for Archaea of the genus Methanosarcina: Liposome-mediated transformation and construction of shuttle vectors. Proc. Natl. Acad. Sci. USA 94:2626-2631.

1998

Mukhopadhyay, B., S. F. Stoddard, and R. S. Wolfe. 1998. Purification, regulation, and molecular and biochemical characterization of pyruvate carboxylase from Methanobacterium thermoautotrophicum strain $\Delta H$. J. Biol. Chem. 273:5155-5166.

Metcalf, W. W., J.-K. Zhang, and R. S. Wolfe. 1998. An anaerobic, intrachamber, incubator for growth of Methanosarcina spp. on methanol-containing solid media. Appl. Environ. Microbiol. 64:768-770.

1999

Mukhopadhyay, B., E. F. Johnson, and R. S. Wolfe. 1999. Reactor-scale cultivation of the hyperthermophilic methanarchaeon Methanococcus jannaschii to high cell densities. Appl. Environ. Microbiol. 65:5059-5065.

Mukhopadhyay, B., E. F. Johnson, M. Ascano, Jr. 1999. Conditions for vigorous growth on sulfide and reactor-scale cultivation protocols for the thermophilic green sulfur bacterium Chlorobium tepidum. Appl. Environ. Microbiol. 65:301-306.

$\underline{2000}$

Mukhopadhyay, B., E. F. Johnson, and R. S. Wolfe. 2000. A novel $\mathrm{p}_{\mathrm{H}}$ control on the expression of flagella in the hyperthermophilic strictly hydrogenotrophic methanarchaeaon Methanococcus jannaschii. Proc. Natl. Acad. Sci. USA 97:1152211527.

Mukhopadhyay, B., V. J. Patel, and R. S. Wolfe. 2000. A stable archaeal pyruvate carboxylase from the hyperthermophile Methanococcus jannaschii. Arch. Microbiol. 174:406-414.

2001

Fàbrega, C., M. A. Farrow, B. Mukhopadhyay, V. de Crécy-Lagard, A. R. Ortiz, and P. Schimmel. A new aminoacyl tRNA synthetase whose sequence fits into neither of the two known classes. Nature (in press).

Mukhopadhyay, B., E. M. Concar, and R. S. Wolfe. A GTP-dependent vertebratetype phosphoenolpyruvate carboxykinase from Mycobacterium smegmatis. J. Biol. Chem. (in press/published on-line on February 8, 2001).

Mukhopadhyay, B., E. Purwantini, C. L. Kreder, and R. S. Wolfe. Oxaloacetate synthesis in the methanarchaeon Methanosarcina barkeri: a pyruvate carboxylase gene and a putative Escherichia coli-type bifunctional biotin protein ligase gene (bpl/birA) exhibit a unique organization. J. Bacteriol. (in press). 


\section{Summary of Progress}

1. Progress reports (1987-1997) have addressed contributions to science supported by this DOE grant and have been documented in publications in 1987 through 1997.

2. 1998. We discovered that Methanobacterium thermoautotrophicum strain $\Delta H$ possessed pyruvate carboxylase (PYC), and this biotin prototroph required exogenously supplied biotin to exhibit detectable amounts of PYC activity. The enzyme was highly labile and was stabilized by $10 \%$ inositol in buffers to an extent that allowed purification to homogeneity and characterization. The purified enzyme was absolutely dependent on ATP, $\mathrm{Mg}^{2+}$ (or $\mathrm{Mn}^{2+}$ or $\mathrm{Co}^{2+}$ ), pyruvate, and bicarbonate for activity; phosphoenolpyruvate could not replace pyruvate, and acetyl-CoA was not required. The enzyme was inhibited by ADP and $\alpha$-ketoglutarate but not by aspartate or glutamate. ATP was inhibitory at high concentrations. The enzyme, unlike other PYCs, exhibited non-linear kinetics with respect to bicarbonate and was inhibited by excess $\mathrm{Mg}^{2+}, \mathrm{Mn}^{2+}$, or $\mathrm{Co}^{2+}$. The 540-kDa enzyme of $\mathrm{A}_{4} \mathrm{~B}_{4}$ composition contained a non-biotinylated 52-kDa subunit (PYCA) and a 75-kDa biotinylated subunit (PYCB). The pycB gene was probably monocistronic and followed by a putative gene of a DNAbinding protein on the opposite strand. The pycA was about 727 kilobase pairs away from $p y c B$ on the chromosome and was probably co-transcribed with the biotin ligase gene (birA). PYCA and PYCB showed substantial sequence identities (33-62\%) to, respectively, the biotin carboxylase and biotin carboxyl carrier + carboxyltransferase domains or subunits of known biotin-dependent carboxylases/decarboxylases. We discovered that PYCB and probably the equivalent domains or subunits of all biotin-dependent carboxylases harbored the serine/threonine dehydratase types of pyridoxal-phosphate attachment site. Our results and the existence of an alternative oxaloacetate synthesizing enzyme phosphoenolpyruvate carboxylase in $M$. thermoautotrophicum strain $\Delta \mathrm{H}$ (Kenealy, W. R., and Zeikus, J. G. [1982] FEMS Microbiol. Lett. 14:7-10) raise several questions for future investigations.

3. 1998. To simplify the incubation of Methanosarcina spp. on solid agar medium, a two-port, manual, rectangular air lock was modified to serve as an anaerobic incubator. In one operation, it is possible to incubate 153 petri plates, the equivalent of 11 standard anaerobic jars, with plating efficiencies identical to those of traditional protocols.

4. 1999. For the hyperthermophilic and barophilic methanarchaeon Methanococcus jannaschii, we have developed a medium and protocols for reactor-scale cultivation that improved the final cell yield per liter from $\sim 0.5$ to $-7.5 \mathrm{~g}$ of packed wet cells ( $-1.8 \mathrm{~g}$ dry cell mass) under autotrophic growth conditions and to $-8.5 \mathrm{~g}$ of packed wet cells ( $-2 \mathrm{~g}$ dry cell mass) with yeast extract ( $\left.2 \mathrm{~g} \mathrm{liter}^{-1}\right)$ and tryptone ( $\left.2 \mathrm{~g} \mathrm{liter}^{-1}\right)$ as medium supplements. For growth in a sealed bottle it was necessary to add Se to the medium, and a level of $2 \mu \mathrm{M}$ 
for added Se gave the highest final cell yield. In a reactor $M$. jannaschii grew without added $\mathrm{Se}$ in the medium; it is plausible that the cells received $\mathrm{Se}$ as a contaminant from the reactor vessel and the $\mathrm{H}_{2} \mathrm{~S}$ supply. But, for the optimal performance of a reactor culture, an addition of Se to a final concentration of 50 to $100 \mu \mathrm{M}$ was needed. Also, cell growth in a reactor culture was inhibited at much higher Se concentrations. These observations and the data from previous work with methanogen cell extracts (B. C. McBride and R. S. Wolfe, Biochemistry 10:4312-4317, 1971) suggested that from a continuously sparged reactor culture Se was lost in the exhaust gas as volatile selenides, and this loss raised the apparent required level of and tolerance for Se. In spite of having a proteinaceous cell wall, $M$. jannaschii withstood an impeller tip speed of 235.5 $\mathrm{cms}^{-1}$, which was optimal for achieving high cell density and also was the higher limit for the tolerated shear rate. The organism secreted one or more acidic compounds, which lowered $\mathrm{pH}$ in cultures without $\mathrm{pH}$ control; this secretion continued even after cessation of growth.

5. 1999. We described a reactor-scale cultivation protocol for the fastest-growing and only known thermophilic member of the family Chlorobiaceae, Chlorobium tepidum. We discovered that $C$. tepidum would grow with sulfide as the sole electron source at rates and with final cell yields comparable to those found with thiosulfate only if the sulfide concentration was maintained below $0.1 \mathrm{mM}$ and the culture redox potential was at $-300 \pm 20 \mathrm{mV}$. Such was also the requirement for growth in a photobioreactor when thiosulfate (optimum level, $12 \mathrm{mM}$ ) was used as the preferred electron source. For cultivation of $C$. tepidum on a 5- to 500-ml scale, we used the system of Balch and Wolfe (Appl. Environ. Microbiol. 32:781-791, 1976) using stopper-sealed serum tubes and bottles as an alternative to the methods commonly used for the cultivation of phototrophic anaerobes and obtained consistent results.

6. 2000. The methanarchaeon, Methanococcus jannaschii, a hyperthermophilic, autotrophic, and strictly hydrogenotrophic inhabitant of submarine hydrothermal vents, was cultivated in a reactor at two hydrogen partial pressure $\left(\mathrm{p}_{\mathrm{H}_{2}}\right)$ values, $178 \mathrm{kPa}$ (high) and $650 \mathrm{~Pa}$ (ultralow), and the cells were subjected to a comparative proteome analysis. From these studies, it was discovered that, when $\mathrm{p}_{\mathrm{H}_{2}}$ was high and the cell density was low (a combination representing a hydrogen-excess condition), the cells possessed very low or undetectable levels of four flagella-related polypeptides (FlaB2, FlaB3, FlaD, and FlaE); electron microscopic examination showed that most of these cells were devoid of flagella. Flagella synthesis occurred when hydrogen became limiting either at high cell density under high $\mathrm{p}_{\mathrm{H}_{2}}$ or at low cell density under low $\mathrm{p}_{\mathrm{H}_{2}}$. The results from a $\mathrm{p}_{\mathrm{H}_{2}}$-shift experiment corroborated the above observations. The $\mathrm{P}_{\mathrm{H}_{2}}{ }^{-}$ dependent changes in the levels of two methanogenic enzymes (MTD and HMDX) were as expected, and thus they served as internal controls. To our knowledge, this is the first example for the regulation of expression of flagella by hydrogen in any domain of life and for a control of any kind on flagella synthesis in the archaea. Our work also provides the only known example for 
each of the following: (i) the pure culture cultivation of a methanogen at an ultralow, near ecologically relevant $\mathrm{p}_{\mathrm{H}_{2}}$; (ii) experimental functional genomics for $M$. jannaschii; and (iii) the use of proteomics with $M$. jannaschii.

7. 2000. The pyruvate carboxylase (PYC) of the hyperthermophilic, strictly hydrogenotrophic, autotrophic and marine methanarchaeon Methanococcus jannaschii was purified to homogeneity. Optimal activity was at $\mathrm{pH} 8.5$, $\geq 80^{\circ} \mathrm{C}$, and a $\mathrm{KCl}$ concentration of $0.175 \mathrm{M}$. This enzyme is the most thermophilic PYC so far studied. Unlike the Methanobacterium thermoautotrophicum enzyme, $M$. jannaschii PYC was expressed in cells grown without an external source of biotin and in the purified form was stable during storage at $4,-20$, and $-80^{\circ} \mathrm{C}$. However, it was rapidly inactivated at $80^{\circ} \mathrm{C}$. The enzyme was insensitive to aspartate and glutamate, mildly inhibited by $\alpha$ ketoglutarate, and was strongly inhibited by ATP and ADP (apparent $K_{\mathrm{m}}$ for ATP, $0.374 \pm 0.039 \mathrm{mM}$; apparent $K_{\mathrm{i}}$ for ATP, $5.34 \pm 2.14 \mathrm{mM} ; K_{\mathrm{i}}$ for ADP, $0.89 \pm 0.18 \mathrm{mM}$ ). It was also strongly inhibited when the $\mathrm{Mg}^{2+}$ concentration in the assay exceeded that of ATP. Thus, this stable PYC could serve as a model for mechanistic studies on archaeal PYCs. It was apparently an $\alpha_{4} \beta_{4}$-type PYC composed of a non-biotinylated 55.5-kDa subunit (PYCA) and a 64.2-kDa biotinylated subunit (PYCB). The determined $\mathrm{NH}_{2}$-terminal sequences for these subunits provided additional support for our earlier proposal to rename the ORFs MJ1229 and MJ1231 in the NCBI M. jannaschii genome sequence database as PYCA and PYCB, respectively; even very recently, these have been misidentified as a subunit of acetyl-CoA carboxylase (AccC) and the $\alpha$-subunit of ion-pumping oxaloacetate decarboxylase $(\mathrm{OAD} \alpha)$, respectively.

8. 2001. To extend knowledge of $\mathrm{CO}_{2}$ fixation by non-methanogenic systems we have studied the pyruvate carboxylase of Mycobacterium smegmatis. Our data suggested that in $M$. smegmatis PYC might not fulfill a straightforward anaplerotic function. Consistent with this idea, our pyc mutant grew in a minimal medium without supplements such as aspartate, glutamate or oxaloacetate. We hypothesized that in $M$. smegmatis PYC may play a gluconeogenic role. A direct corollary of this hypothesis was that $M$. smegmatis would possess a phosphoenolpyruvate carboxykinase (PCK) that kinetically prefers the PEP synthesis direction. We cloned and expressed the $M$. smegmatis PCK with high activity in $E$. coli. We purified the recombinant enzyme (rMsmPCK) to homogeneity and characterized it. The rMsmPCK was a strictly GTP-dependent vertebrate-type enzyme; this was the first such report for the bacteria. As we hypothesized, the mycobacterial PCK preferred the gluconeogenesis direction. Only two other bacterial GTP-PCKs are known, and they play anaplerotic roles. Both in its primary structure and kinetic properties, the mycobacterial PCK showed extraordinary similarities to the vertebrate-liver enzymes. Also, rMsmPCK can be obtained in large quantities from the recombinant $E$. coli with great ease and in an extraordinary stable form $\left(4^{\circ} \mathrm{C} / 2\right.$ months). All these attributes would make the mycobacterial GTP-PCK a great model for enzyme structure function studies in this field. 
9. 2001. In collaboration with Professor Shimmel's laboratory a new aminoacyl tRNA synthetase from Methanococcus jannaschii was discovered whose sequence fits into neither of the two known classes.

10. 2001. To continue our studies on $\mathrm{CO}_{2}$ fixation in methanogens we studied a pyruvate carboxylase in Methanosarcina barkeri. We found that in Methanosarcina barkeri oxaloacetate synthesis, an essential and major $\mathrm{CO}_{2}$ fixation reaction, is catalyzed by an apparent $\alpha_{4} \beta_{4}$-type acetyl-CoA-independent pyruvate carboxylase (PYC), composed of $64.2 \mathrm{kDa}$ biotinylated (PYCB) and $52.9 \mathrm{kDa}$ ATP-binding (PYCA) subunits. The purified enzyme was most active at $70^{\circ} \mathrm{C}$, insensitive to aspartate and glutamate, mildly inhibited by $\alpha$ ketoglutarate, and severely inhibited by ATP, ADP, and excess $\mathrm{Mg}^{2+}$. It showed negative cooperativity towards bicarbonate at $70^{\circ} \mathrm{C}$, but not at $37^{\circ} \mathrm{C}$. The organism expressed holo-PYC without an external supply of biotin and thus, synthesized biotin. $p y c A, p y c B$, and a putative $b p l$ (biotin protein ligase gene) formed a novel operon-like arrangement. Unlike other archaeal homologs, the putative BPLs of $M$. barkeri and the closely related euryarchaeon Archaeoglobus fulgidus appeared to be $E$. coli-type (bifunctional: BirA or repressor of biotin operon and BPL). We found the element $\operatorname{Tyr}(\mathrm{Phe}) \operatorname{Pro} \mathrm{X}_{5} \mathrm{Phe}(\mathrm{Tyr})$ to be fully conserved in biotin-dependent enzymes; it might function as the hinge for their "swinging arms."

\section{APPENDIX}

Seven reprints not previously provided to DOE are appended. 


\section{SUMMARY SHEET OF \\ ITEMS INCLUDED IN THE APPENDIX \\ FOR FINAL DOE TECHNICAL REPORT \\ Ralph S. Wolfe, Principal Investigator \\ Title of Project: Studies on the Microbial Formation of Methane}

1. Mukhopadhyay, B., E. Purwantini, C. L. Kreder, and R. S. Wolfe. Oxaloacetate synthesis in the methanarchaeon Methanosarcina barkeri: a pyruvate carboxylase gene and a putative Escherichia coli-type bifunctional biotin protein ligase gene ( $\mathrm{bpl} / \mathrm{birA}$ ) exhibit a unique organization. J. Bacteriol. (in press).

2. Mukhopadhyay, B., V. J. Patel, and R. S. Wolfe. 2000. A stable archaeal pyruvate carboxylase from the hyperthermophile Methanococcus jannaschii. Arch. Microbiol. 174:406-414.

3. Mukhopadhyay, B., E. F. Johnson, and R. S. Wolfe. 2000. A novel $\mathrm{p}_{\mathrm{H}_{2}}$ control on the expression of flagella in the hyperthermophilic strictly hydrogenotrophic methanarchaeaon Methanococcus jannaschii. Proc. Natl. Acad. Sci. USA 97:11522-11527.

4. Mukhopadhyay, B., E. M. Concar, and R. S. Wolfe. A GTP-dependent vertebrate-type phosphoenolpyruvate carboxykinase from Mycobacterium smegmatis. J. Biol. Chem. (in press/published on-line on February 8, 2001).

5. Mukhopadhyay, B., and E. Purwantini. 2000. Pyruvate carboxylase from Mycobacterium smegmatis: stabilization, rapid purification, molecular and biochemical characterization and regulation of the cellular level. Biochim. Biophys. Acta 1475:191-206.

6. Mukhopadhyay, B., E. F. Johnson, and R. S. Wolfe. 1999. Reactor-scale cultivation of the hyperthermophilic methanarchaeon Methanococcus jannaschii to high cell densities. Appl. Environ. Microbiol. 65:5059-5065.

7. Mukhopadhyay, B., E. F. Johnson, M. Ascano, Jr. 1999. Conditions for vigorous growth on sulfide and reactor-scale cultivation protocols for the thermophilic green sulfur bacterium Chlorobium tepidum. Appl. Environ. Microbiol. 65:301-306. 